\title{
Menaquinone Composition in the Classification of Streptomyces and Other Sporoactinomycetes
}

\author{
By G. ALDERSON ${ }^{1 *}$ M. GOODFELLOW ${ }^{2}$ AND D. E. MINNIKIN ${ }^{2}$ \\ ${ }^{1}$ School of Studies in Medical Sciences, University of Bradford, Bradford BD7 1DP, UK \\ ${ }^{2}$ Departments of Microbiology and Organic Chemistry, The University, Newcastle upon Tyne \\ $N E 17 R U, U K$
}

(Received 26 November 1984; revised 13 February 1985)

\begin{abstract}
The menaquinones of 59 actinomycetes representing Streptomyces, Streptoverticillium and related taxa were examined by mass spectrometry and the results compared with those of an earlier numerical phenetic survey. The Streptomyces and Streptoverticillium strains contained complex mixtures of partially saturated menaquinones with nine isoprene units with the hexaand/or octahydrogenated components predominating. The detection of essentially similar menaquinones in representatives of the genera Chainia, Elytrosporangium, Kitasatoa and Microellobosporia is consistent with the suggestion that these taxa be reduced to synonyms of the genus Streptomyces. The recovery of markedly different menaquinones from representatives of Nocardiopsis dassonvillei and Saccharopolyspora hirsuta, together with chemical data from previous studies, clearly show that these taxa should not be associated with the Streptomyces cluster-group, contrary to the results of the numerical phenetic survey. Streptomycetes can also be distinguished from other actinomycetes including those strains of Nocardia lacking mycolic acids. The results show that menaquinone composition is of value in both the classification and the identification of streptomycetes. Indeed, the present data suggest that the minimum description of the genus Streptomyces should include information on menaquinone composition.
\end{abstract}

\section{INTRODUCTION}

The genus Streptomyces currently contains aerobic, Gram-positive, highly oxidative actinomycetes which usually form a stable substrate mycelium with aerial mycelium bearing long chains of conidia. Streptomycetes have a wall chemotype I, that is, they contain LLdiaminopimelic acid and glycine but no characteristic sugar in the peptidoglycan (Lechevalier \& Lechevalier, 1970). The confused state of streptomycete systematics (Sneath, 1970; Kutzner, 1981) has made it difficult to choose representative strains for taxonomic studies (Ridell \& Williams, 1983; Gladek et al., 1985), while it can be difficult to distinguish Streptomyces from related wall chemotype I taxa and from Actinomadura, Nocardiopsis and Nocardia strains that lack mycolic acids (Gordon \& Horan, 1968; Lacey et al., 1978; Goodfellow \& Pirouz, 1982; Goodfellow \& Haynes, 1984; Goodfellow \& Minnikin, 1984). However, in a recent numerical phenetic study of Streptomyces and related genera (Williams et al., 1983) most of the 394 Streptomyces type cultures fell into an aggregate taxon, cluster-group A, that encompassed 19 major, 14 minor and 18 single-member clusters. Some streptomycete taxa, notably $S$. clavuligerus, $S$. fradiae, $S$. lavendulae and $S$. rimosus, were recovered in distinct but less stable cluster-groups while $S$. lavendulae and related organisms not only consistently fell outside the Streptomyces cluster-group but shared a relatively high overall similarity to the Kitasatoa and Streptoverticillium strains in cluster-group F.

Isoprenoid quinones are characteristic components of most bacterial membranes and those from actinomycetes are exclusively menaquinones, that is, 2-methyl-3-polyprenyl-1,4-naphthoquinones (Collins \& Jones, 1981; Collins et al., 1985). The taxonomic value of menaquinones lies 
in the variation in the length and degree of unsaturation of the $\mathrm{C}_{3}$ isoprenyl side-chain. Much of the data on the menaquinone composition of actinomycetes has come from analyses of actinobacteria and nocardioform actinomycetes (Goodfellow \& Cross, 1984; Collins et al., 1985). In contrast, sporoactinomycetes have received somewhat less attention (Lester \& Crane, 1959; Campbell et al., 1971 ; Dunphy et al., 1971; Batrakov et al., 1976; Collins et al., 1977, 1980, 1982, 1984, 1985; Yamada et al., 1977a; Fischer et al., 1983; Athalye et al., 1984). It was therefore decided to determine the menaquinone composition of judiciously chosen representatives of the taxa defined by Williams et al. (1983) in order to evaluate the integrity of the phenetic groups and the potential value of menaquinones in the circumscription of the genus Streptomyces and its differentiation from related taxa.

\section{METHODS}

Cultures. The test strains (Tables 1 and 2) were stored on yeast/malt extract agar slants (Pridham et al., 19561957) both at room temperature and at $-25^{\circ} \mathrm{C}$, and on slopes of modified Bennett's agar (Jones, 1949) with glucose replaced by glycerol, at $4{ }^{\circ} \mathrm{C}$. In addition, spore or mycelial fragment suspensions were stored in glycerol $(20 \%, v / v)$ at $-20^{\circ} \mathrm{C}$ (Wellington \& Williams, 1978). Detailed histories of the test strains can be found elsewhere (Williams et al., 1983). Binomials in inverted commas are not on the Approved Lists of Bacterial Names (Skerman et al., 1980) and have not been validly published since 1 January 1980.

Growth conditions. The strains were grown in shake flasks of modified Sauton's broth (Mordarska et al., 1972) for 5 to $7 \mathrm{~d}$ at $30^{\circ} \mathrm{C}$. At maximum growth, cultures were checked for purity, killed with formaldehyde $(1 \%, v / v)$, harvested by centrifugation, washed twice with distilled water and freeze-dried.

Extraction and analysis of isoprenoid quinones. Dried organisms (about $100 \mathrm{mg}$ ) were extracted by a recently developed procedure involving shaking with a biphasic mixture of equal amounts of methanol $/ 0.3 \%$ aqueous sodium chloride $(10: 1, \mathrm{v} / \mathrm{v})$ and petroleum ether (b.p. $60-80^{\circ} \mathrm{C}$ ) followed by preparative thin layer chromatography (TLC) (Athalye et al., 1984; Minnikin et al., 1984). Reverse phase TLC was done according to Collins et al. (1980). Mass spectra of the purified menaquinones were recorded on an AEI MS9 instrument using a direct insertion probe, an ionizing voltage of $70 \mathrm{eV}$ and a temperature range of 200 to $220^{\circ} \mathrm{C}$.

\section{RESULTS AND DISCUSSION}

The lipid extracts of all of the test strains contained menaquinones which cochromatographed with standards of vitamin $\mathrm{K}$. The most intense peaks in the mass spectra occurred at $m / z \quad 187$ and 225 and were derived from the naphthoquinone nucleus. The mass spectra of the menaquinone samples in the high mass region contained strong peaks corresponding to molecular ions $\left(\mathrm{M}^{+}\right)$, with smaller peaks at $\mathbf{M}^{+-15}$, corresponding to the loss of a methyl group from the molecular ions. The results of the mass spectral analyses are shown in Tables 1 and 2, the patterns of representative strains being checked by reverse phase TLC.

Without exception, all of the representative strains of Streptomyces from cluster-group A contained complex mixtures of partially saturated menaquinones with nine isoprene units (Table 1). The detection of major amounts of hexa- and octahydrogenated menaquinones with nine isoprene units, abbreviated as $\mathrm{MK}-9\left(\mathrm{H}_{6}\right)$ and $\mathrm{MK}-9\left(\mathrm{H}_{8}\right)$, in the cluster-group A strains is in good agreement with reports of similar menaquinone profiles in Streptomyces albus (Campbell et al., 1971; Collins et al., 1984), S. fradiae (Collins et al., 1985), S. griseochromogenes (Collins, 1982; Collins et al., 1985), S. olivaceus (Batrakov et al., 1976; Batrakov \& Bergelson, 1978), $S$. platensis (Collins et al., 1980, 1985), S. rimosus (Collins et al., 1985), S. somaliensis (Collins et al., 1977; Athalye et al., 1984), S. xantholyticus (Collins et al., 1985), S. viridochromogenes (Collins et al., 1984) and Streptomyces spp. (Collins et al., 1977; Dunphy et al., 1971; Phillips et al., 1971). The presence of essentially similar menaquinone profiles in $S$. clavuligerus, $S$. lavendulae and $S$. rimosus, and in all but one of the streptomycetes which fell outside the Streptomyces clustergroup (Williams et al., 1983) is not unexpected as all of the excluded organisms exhibit properties characteristic of typical members of the genus Streptomyces (Lechevalier \& Lechevalier, 1970; Shirling \& Gottlieb, 1968a, b, 1969, 1972; Pridham \& Lyons, 1969). In addition, the $S$. lavendulae strain is lysed by phage virulent for Streptomyces (Prauser, 1976 a) and has been recovered in a rRNA homology group corresponding to the genus Streptomyces (Gładek et al., 1985). The menaquinone data lend support to the view (Williams et al., 1983) that 
layer chromatography. Journal of Applied Bacterio$\log y$ 48, 277-282.

Collins, M. D., MCCarthy, A. J. \& Cross, T. (1982). New highly saturated members of the vitamin $\mathrm{K}_{2}$ series from Thermomonospora. Zentralblatt für Bakteriologie, Parasitenkunde, Infektionskrankheiten und Hygiene (Abteilung I, Originale C) 3, 358-363.

Collins, M. D., Keddie, R. M. \& Kroppenstedt, R. M. (1983). Lipid composition of Arthrobacter simplex, Arthrobacter tumescens and possibly related taxa. Systematic and Applied Microbiology 4, 18-26.

Collins, M. D., Faulkner, M. \& Keddie, R. M. (1984). Menaquinone composition of some sporeforming actinomycetes. Systematic and Applied Microbiology 5, 20-29.

Collins, M. D., Goodfellow, M., Minnikin, D. E. \& Alderson, G. (1985). Menaquinone composition of mycolic acid-containing actinomycetes and some sporoactinomycetes. Journal of Applied Bacteriology 58, $77-86$

Dunphy, P. J., Phillips, P. G. \& Brodie, A. F. (1971). Separation and identification of menaquinones from microorganisms. Journal of Lipid Research 12, 422449.

Fischer, A., K ROPPENSTEDT, R. M. \& STACKebRaNDT, E. (1983). Molecular-genetic and chemotaxonomic studies on Actinomadura and Nocardiopsis. Journal of General Microbiology 129, 3433-3446.

Gladek, A., Mordarski, M., Goodfellow, M. \& Williams, S. T. (1985). Ribosomal ribonucleic acid similarities in the classification of Streptomyces. FEMS Microbiology Letters 26, 175-180.

Goodfellow, M. \& Cross, T. (1984). Classification. In The Biology of the Actinomycetes, pp. 7-164. Edited by M. Goodfellow, M. Mordarski \& S. T. Williams. London \& New York: Academic Press.

Goodfellow, M. \& Haynes, J. A. (1984). Actinomycetes in marine sediments. In Biological, Biochemical and Biomedical Aspects of Actinomycetes, pp. 453472. Edited by L. Ortiz-Ortiz, L. F. Bojalil \& V. Yakoleff. Orlando: Academic Press.

Goodfellow, M. \& MinNIKIN, D. E. (1984). A critical evaluation of Nocardia and related taxa. In Biological, Biochemical and Biomedical Aspects of Actinomycetes, pp. 483-496. Edited by L. Ortiz-Ortiz, L. F. Bojalil \& V. Yakoleff. Orlando: Academic Press.

Goodfellow, M. \& Pirouz, T. (1982). Numerical classification of sporoactinomycetes containing meso-diaminopimelic acid in the cell wall. Journal of General Microbiology 128, 503-527.

Goodfellow, M., Weaver, C. R. \& Minnikin, D. E. (1982). Numerical classification of some rhodococci, corynebacteria and related organisms. Journal of General Microbiology 128, 731-745.

Gordon, R. E. \& HoRAN, A. C. (1968). Nocardia dassonvillei, a macroscopic replica of Streptomyces griseus. Journal of General Microbiology 50, 235-240.

JONES, K. L. (1949). Fresh isolates of actinomycetes in which the presence of sporogenous aerial mycelia is a fluctuating characteristic. Journal of Bacteriology 57, 141-145.

KROPPENSTEDT, R. M. (1982). Separation of bacterial menaquinones by high performance liquid chromatography using reverse phase (RP-18) and a silver loaded ion exchanger as stationary phases. Journal of Liquid Chromatography 5, 2359-2369.
KROPPENSTEDT, R. M. (1985). Fatty acid and menaquinone analysis of actinomycetes and related organisms. In Chemical Methods in Bacterial Systematics, pp. 173-199. Edited by M. Goodfellow \& D. E. Minnikin. Orlando: Academic Press.

KROPPENSTEDT, R. M., KORN-WENDICH, F., FOWLER, V. J. \& STACKEBRANDT, E. (1981). Biochemical and molecular genetic evidence for a transfer of Actinoplanes armeniacus into the family Streptomycetaceae. Zentralblatt für Bakteriologie, Mikrobiologie und Hygiene (Abteilung I, Originale C) 2, 254-262.

KutZner, H. J. (1981). Streptomycetaceae. In The Prokaryotes: a Handbook of Habitats, Isolation and Identification of Bacteria, pp. 2028-2090. Edited by M. P. Starr, H. Stolp, H. G. Trüper, A. Balows \& H. G. Schlegel. Berlin: Springer Verlag.

L.ACEY, J. \& GoOdFEllow, M. (1975). A novel actinomycete from sugar-cane bagasse: Saccharopolyspora hirsuta gen. et sp. nov. Journal of General Microbiology 88, 75-85.

Lacey, J., Goodfellow, M. \& Alderson, G. (1978). The genus Actinomadura Lechevalier and Lechevalier. Zentralblatt für Bakteriologie, Parasitenkunde, Infektionskrankheiten und Hygiene (Abteilung I, Supplement 6), 107-117.

Lechevalier, M. P. \& Lechevalier, H. A. (1970). Chemical composition as a criterion in the classification of aerobic actinomycetes. International Journal of Systematic Bacteriology 20, 435-443.

LecheValier, M. P., DE Bievre, C. \& Lechevalier, H. A. (1977). Chemotaxonomy of aerobic actinomycetes: phospholipid composition. Biochemical Systematics and Ecology 5, 249-260.

Lester, R. L. \& CRANE, F. L. (1959). The natural occurrence of coenzyme $\mathrm{Q}$ and related compounds. Journal of Biological Chemistry 234, 2169-2175.

Minnikin, D. E., O'Donnell, A. G., Goodfellow, M., Alderson, G., Athalye, M., Schaal, A. \& Parlett, J. H. (1984). An integrated procedure for the extraction of bacterial isoprenoid quinones and polar lipids. Journal of Microbiological Methods 2, 233-241.

MordarsKa, H., Mordarski, M. \& Goodfellow, M. (1972). Chemotaxonomic characters and classification of some nocardioform bacteria. Journal of General Microbiology 71, 77-86.

O'Donnell, A. G., Goodfellow, M. \& Minnikin, D. E. (1982). Lipids in the classification of Nocardioides: reclassification of Arthrobacter simplex (Jensen) Lochhead in the genus Nocardioides (Prauser) emend. O'Donnell et al. as Nocardioides simplex comb. nov. Archives of Microbiology 133, 323-329.

Phillips, P. G., Dunphy, P. J., Servis, K. L. \& BRoDIE, A. F. (1971). A new menaquinone series differing in the degree of unsaturation of the side chain. Biochemistry 8, 2856 2861.

Prauser, H. (1976a). Host-phage relationships in nocardioform organisms. In The Biology of the Nocardiae, pp. 266-284. Edited by M. Goodfellow, G. H. Brownell \& J. A. Serrano. London \& New York: Academic Press.

PraUSER, H. (1976b). Nocardioides, a new genus of the order Actinomycetales. International Journal of Systematic Bacteriology 26, 58-65.

Pridham, T. G. \& Lyons, A. J., JR (1969). Progress in clarification of the taxonomic and nomenclatural 


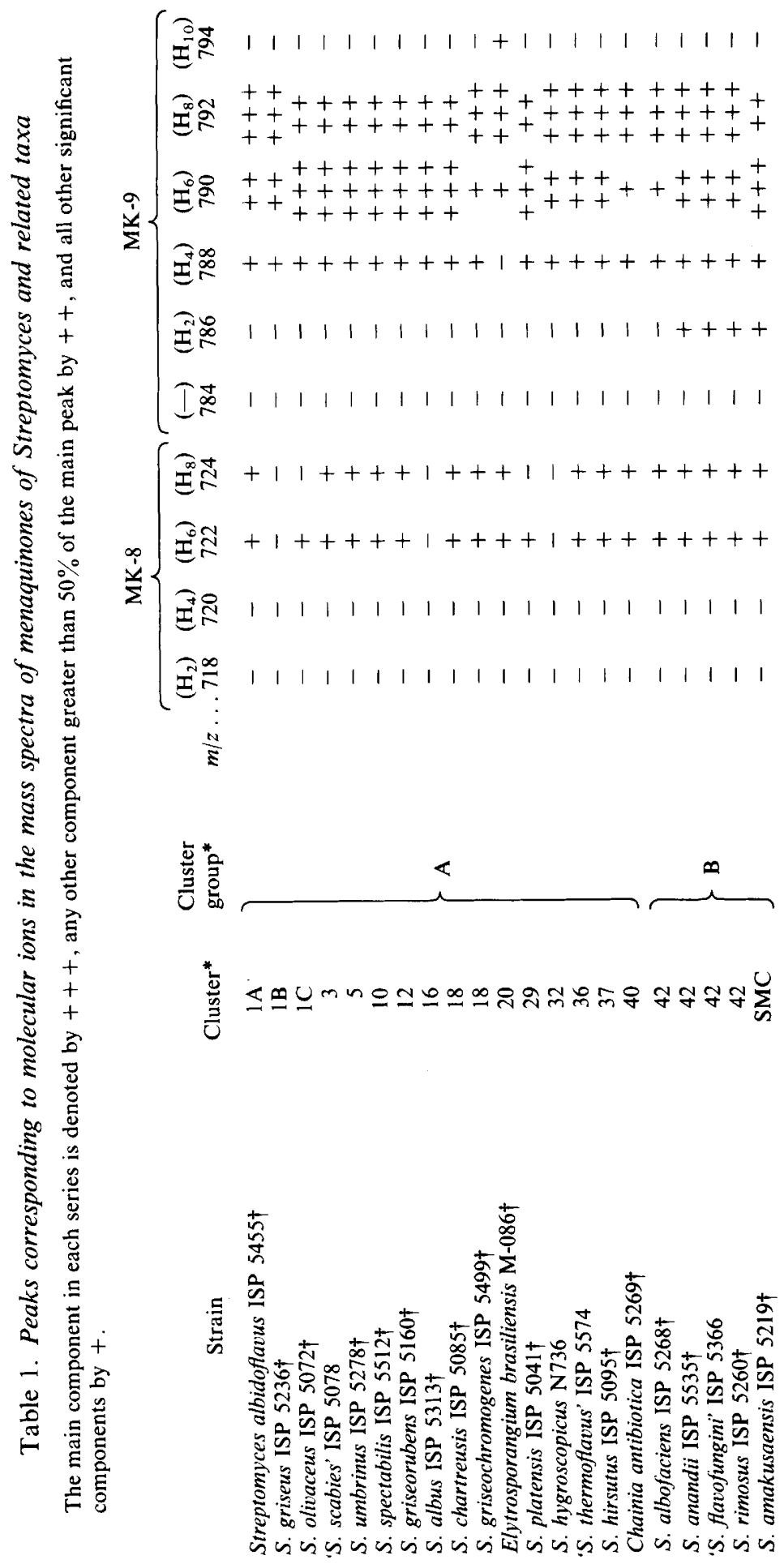




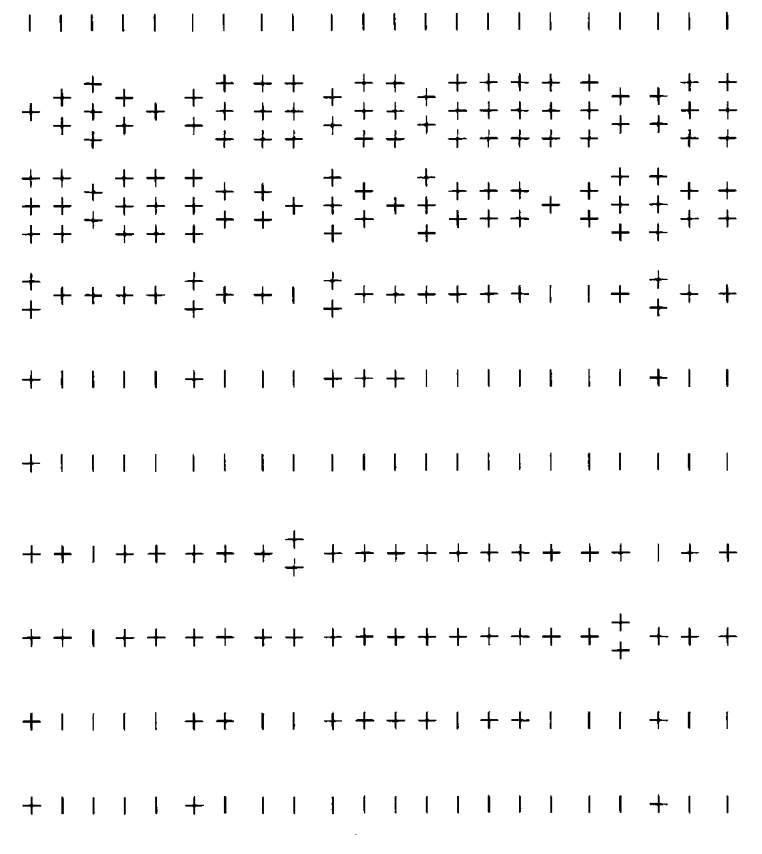

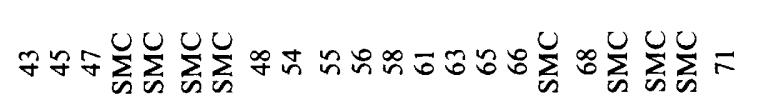
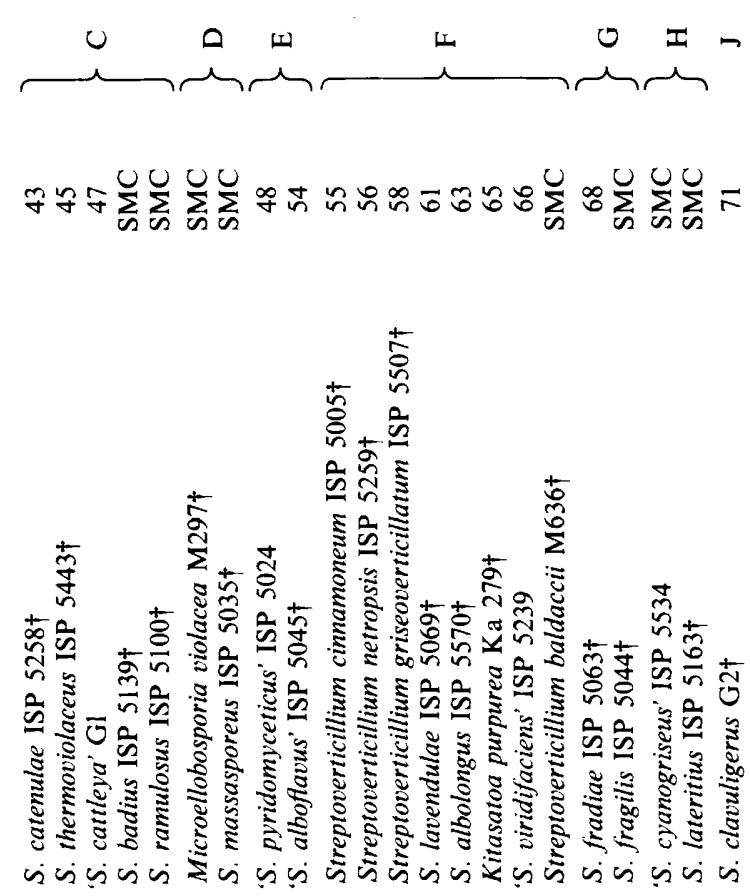


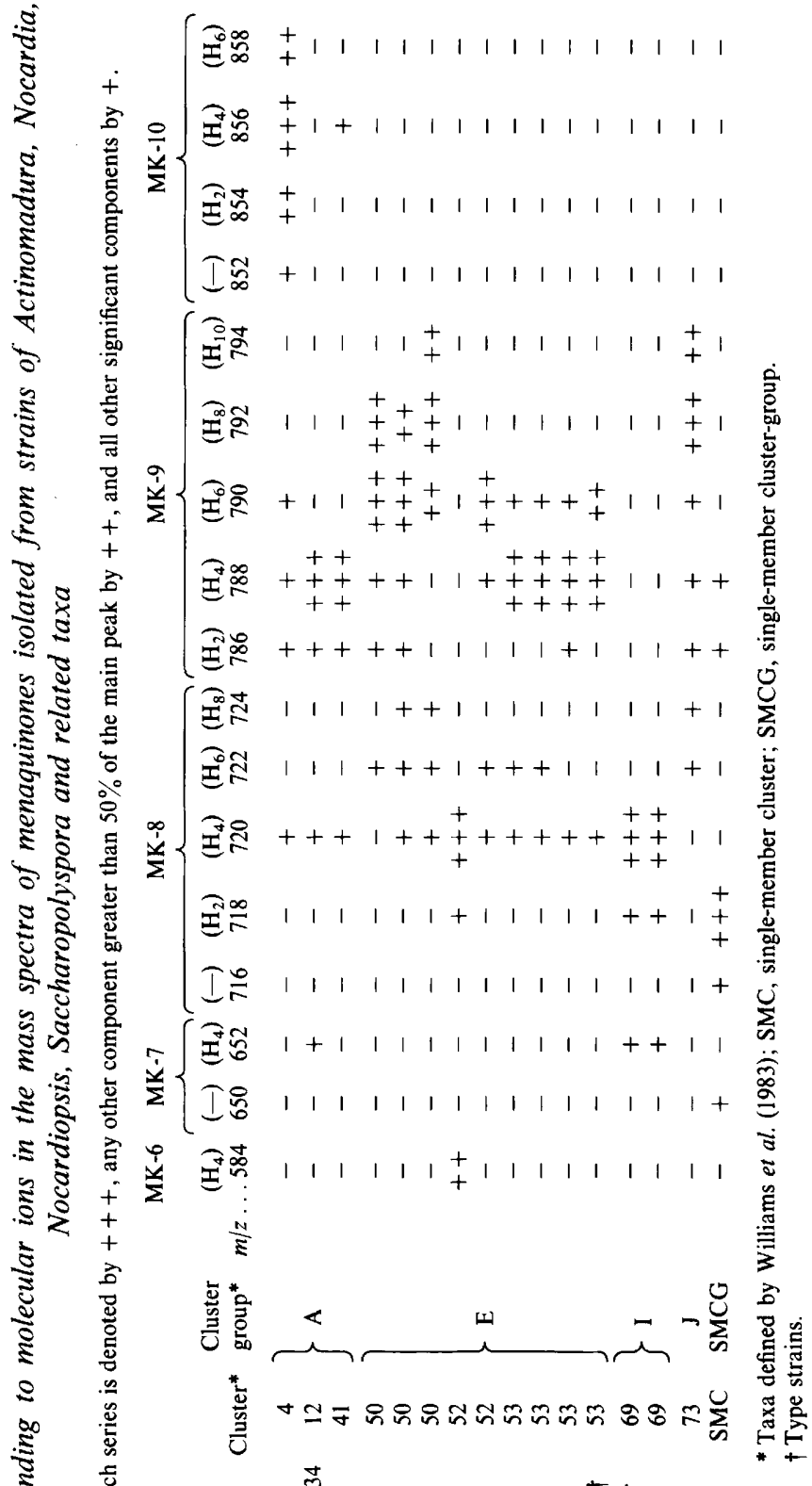

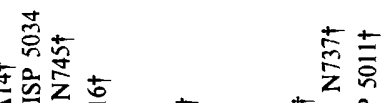

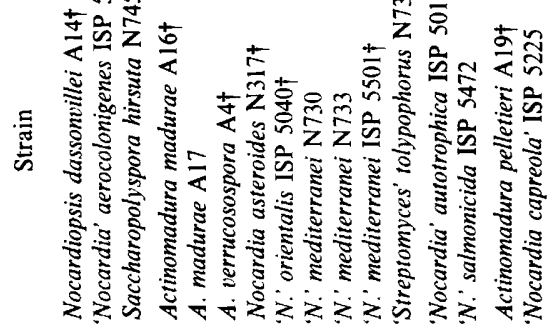


1977; Goodfellow et al., 1982). Indeed, it seems likely that the association of Nocardioides albus, Nocardiopsis dassonvillei and Saccharopolyspora hirsuta with Streptomyces (Williams et al., 1983) is not firmly based. Thus, while Nocardioides strains have a wall chemotype I, they are resistant to phage virulent to Streptomyces (Prauser 1976a, b; Wellington \& Williams, 1978) and have been distinguished from the latter in DNA :DNA pairing (Tille et al., 1978) and lipid analyses (Lechevalier et al., 1977; O'Donnell et al., 1982; Collins et al., 1983). Similarly, Nocardiopsis dassonvillei differs from Streptomyces in its wall chemotype (Lechevalier \& Lechevalier, 1970), resistance to streptomycete phages (Wellington \& Williams, 1981), rRNA oligonucleotide sequences (Stackebrandt \& Woese, 1981) as well as on the basis of menaquinone composition. In addition to menaquinone content, Saccharopolyspora hirsuta can be separated from Streptomyces by wall chemotype (Lacey \& Goodfellow, 1975) and its resistance to phages virulent for streptomycetes.

The present study has confirmed and extended our knowledge on the menaquinone composition of sporoactinomycetes with a wall chemotype I and has provided further evidence of the value of these compounds in the systematics of actinomycetes. In a narrower context, the menaquinone profiles have helped to clarify some of the apparent anomalies in the recent numerical phenetic classification of Streptomyces and related taxa (Williams et al., 1983). The menaquinone data also support the integrity of the genus Streptomyces and heip to distinguish it from actinomycete taxa including Kineosporia, Nocardioides, Nocardiopsis, Saccharopolyspora and sundry Nocardia strains lacking mycolic acids. Despite improvements in streptomycete systematics there is still a dearth of good characters for the description of the genus. The present findings raise the question as to whether data on menaquinone composition should form part of the minimum description of the genus Streptomyces. Mass spectrometric analyses, as used in the present study, provide precise information concerning the overall molecular composition of the principal menaquinone components. Complementary analyses using high performance liquid chromatography provide quantitative profiles (Kroppenstedt, 1982, 1985; Collins et al., 1984) which allow minor components to be observed more clearly and the significance of variations in the proportions of the isoprenologues to be evaluated. It would be of value to apply this latter technique to a similar number of streptomycetes and related taxa but studies should also be done to assess the stability of such menaquinone profiles under varying culture conditions.

M. G. gratefully acknowledges support from the Science and Engineering Research Council (grants GR/A/04309, GR/A/8552). Mass spectra were recorded by S. H. Addison and P. Kelly.

\section{REFERENCES}

Alderson, G., Goodfellow, M., Wellington, E. M. H., Williams, S. T., Minnikin, S. M. \& Minnikin, D. E. (1981). Chemical and numerical taxonomy of Nocardia mediterranei. Zentralblatt für Bakteriologie, Mikrobiologie und Hygiene (Abteilung I, Supplement 11), 39-46.

Aoki, K., Yamada, Y. \& Tahara, Y. (1980). A new natural quinone, 2-methyl-3-II,III, VIII-hexahydromultiprenyl ${ }^{9}-1,4$-naphthoquinone. Agricultural and Biological Chemistry 44, 1963-1965.

Athalye, M., Goodfellow, M. \& Minnikin, D. E. (1984). Menaquinone composition in the classification of Actinomadura and related taxa. Journal of General Microbiology 130, 817-823.

Batrakov, S. G. \& Bergelson, L. D. (1978). Lipids of the streptomycetes. Structural investigation and biological interrelation. Chemistry and Physics of Lipids 21, 1-29.

Batrakov, S. G., Panosyan, A. G., Rosynov, B. V., Konova, I. V. \& Bergelson, L. D. (1976). Menaquinones of Actinomyces olivaceus: on the structures of MK-9 $\left(\mathrm{H}_{6}\right)$, MK-9 $\left(\mathrm{H}_{8}\right)$, MK-8 $\left(\mathrm{H}_{6}\right)$ and MK-8 $\left(\mathrm{H}_{8}\right)$. Bioorganicheskaya Khimiya 2, 1538-1546.

Campbell, I. M., Robins, D. J., Kelsey, M. \& BENTLEY, R. (1971). Biosynthesis of bacterial menaquinones (vitamin $\mathrm{K}_{2}$ ). Biochemistry 10, 3069-3078.

Collins, M. D. (1982). A note on the separation of natural mixtures of bacterial menaquinones using reverse-phase high-performance liquid chromatography. Journal of Applied Bacteriology 52, 457460.

Collins, M. D. \& Jones, D. (1981). Distribution of isoprenoid quinone structural types in bacteria and their taxonomic implications. Microbiological Reviews 45, 316-354.

Collins, M. D., Pirouz, T., Goodfellow, M. \& MINNIKIN, D. E. (1977). Distribution of menaquinones in actinomycetes and corynebacteria. Journal of General Microbiology 100, 221-230.

Collins, M. D., Shah, H. N. \& Minnikin, D. E. (1980). A note on the separation of natural mixtures of bacterial menaquinores using reverse phase thin- 
layer chromatography. Journal of Applied Bacterio$\log y$ 48, 277-282.

Collins, M. D., MCCarthy, A. J. \& Cross, T. (1982). New highly saturated members of the vitamin $\mathrm{K}_{2}$ series from Thermomonospora. Zentralblatt für Bakteriologie, Parasitenkunde, Infektionskrankheiten und Hygiene (Abteilung I, Originale C) 3, 358-363.

Collins, M. D., Keddie, R. M. \& Kroppenstedt, R. M. (1983). Lipid composition of Arthrobacter simplex, Arthrobacter tumescens and possibly related taxa. Systematic and Applied Microbiology 4, 18-26.

Collins, M. D., Faulkner, M. \& Keddie, R. M. (1984). Menaquinone composition of some sporeforming actinomycetes. Systematic and Applied Microbiology 5, 20-29.

Collins, M. D., Goodfellow, M., Minnikin, D. E. \& Alderson, G. (1985). Menaquinone composition of mycolic acid-containing actinomycetes and some sporoactinomycetes. Journal of Applied Bacteriology 58, $77-86$

Dunphy, P. J., Phillips, P. G. \& Brodie, A. F. (1971). Separation and identification of menaquinones from microorganisms. Journal of Lipid Research 12, 422449.

Fischer, A., K ROPPENSTEDT, R. M. \& STACKebRaNDT, E. (1983). Molecular-genetic and chemotaxonomic studies on Actinomadura and Nocardiopsis. Journal of General Microbiology 129, 3433-3446.

Gladek, A., Mordarski, M., Goodfellow, M. \& Williams, S. T. (1985). Ribosomal ribonucleic acid similarities in the classification of Streptomyces. FEMS Microbiology Letters 26, 175-180.

Goodfellow, M. \& Cross, T. (1984). Classification. In The Biology of the Actinomycetes, pp. 7-164. Edited by M. Goodfellow, M. Mordarski \& S. T. Williams. London \& New York: Academic Press.

Goodfellow, M. \& Haynes, J. A. (1984). Actinomycetes in marine sediments. In Biological, Biochemical and Biomedical Aspects of Actinomycetes, pp. 453472. Edited by L. Ortiz-Ortiz, L. F. Bojalil \& V. Yakoleff. Orlando: Academic Press.

Goodfellow, M. \& MinNIKIN, D. E. (1984). A critical evaluation of Nocardia and related taxa. In Biological, Biochemical and Biomedical Aspects of Actinomycetes, pp. 483-496. Edited by L. Ortiz-Ortiz, L. F. Bojalil \& V. Yakoleff. Orlando: Academic Press.

Goodfellow, M. \& Pirouz, T. (1982). Numerical classification of sporoactinomycetes containing meso-diaminopimelic acid in the cell wall. Journal of General Microbiology 128, 503-527.

Goodfellow, M., Weaver, C. R. \& Minnikin, D. E. (1982). Numerical classification of some rhodococci, corynebacteria and related organisms. Journal of General Microbiology 128, 731-745.

Gordon, R. E. \& HoRAN, A. C. (1968). Nocardia dassonvillei, a macroscopic replica of Streptomyces griseus. Journal of General Microbiology 50, 235-240.

JONES, K. L. (1949). Fresh isolates of actinomycetes in which the presence of sporogenous aerial mycelia is a fluctuating characteristic. Journal of Bacteriology 57, 141-145.

KROPPENSTEDT, R. M. (1982). Separation of bacterial menaquinones by high performance liquid chromatography using reverse phase (RP-18) and a silver loaded ion exchanger as stationary phases. Journal of Liquid Chromatography 5, 2359-2369.
KROPPENSTEDT, R. M. (1985). Fatty acid and menaquinone analysis of actinomycetes and related organisms. In Chemical Methods in Bacterial Systematics, pp. 173-199. Edited by M. Goodfellow \& D. E. Minnikin. Orlando: Academic Press.

KROPPENSTEDT, R. M., KORN-WENDICH, F., FOWLER, V. J. \& STACKEBRANDT, E. (1981). Biochemical and molecular genetic evidence for a transfer of Actinoplanes armeniacus into the family Streptomycetaceae. Zentralblatt für Bakteriologie, Mikrobiologie und Hygiene (Abteilung I, Originale C) 2, 254-262.

KutZner, H. J. (1981). Streptomycetaceae. In The Prokaryotes: a Handbook of Habitats, Isolation and Identification of Bacteria, pp. 2028-2090. Edited by M. P. Starr, H. Stolp, H. G. Trüper, A. Balows \& H. G. Schlegel. Berlin: Springer Verlag.

L.ACEY, J. \& GoOdFEllow, M. (1975). A novel actinomycete from sugar-cane bagasse: Saccharopolyspora hirsuta gen. et sp. nov. Journal of General Microbiology 88, 75-85.

Lacey, J., Goodfellow, M. \& Alderson, G. (1978). The genus Actinomadura Lechevalier and Lechevalier. Zentralblatt für Bakteriologie, Parasitenkunde, Infektionskrankheiten und Hygiene (Abteilung I, Supplement 6), 107-117.

Lechevalier, M. P. \& Lechevalier, H. A. (1970). Chemical composition as a criterion in the classification of aerobic actinomycetes. International Journal of Systematic Bacteriology 20, 435-443.

LecheValier, M. P., DE Bievre, C. \& Lechevalier, H. A. (1977). Chemotaxonomy of aerobic actinomycetes: phospholipid composition. Biochemical Systematics and Ecology 5, 249-260.

Lester, R. L. \& CRANE, F. L. (1959). The natural occurrence of coenzyme $\mathrm{Q}$ and related compounds. Journal of Biological Chemistry 234, 2169-2175.

Minnikin, D. E., O'Donnell, A. G., Goodfellow, M., Alderson, G., Athalye, M., Schaal, A. \& Parlett, J. H. (1984). An integrated procedure for the extraction of bacterial isoprenoid quinones and polar lipids. Journal of Microbiological Methods 2, 233-241.

MordarsKa, H., Mordarski, M. \& Goodfellow, M. (1972). Chemotaxonomic characters and classification of some nocardioform bacteria. Journal of General Microbiology 71, 77-86.

O'Donnell, A. G., Goodfellow, M. \& Minnikin, D. E. (1982). Lipids in the classification of Nocardioides: reclassification of Arthrobacter simplex (Jensen) Lochhead in the genus Nocardioides (Prauser) emend. O'Donnell et al. as Nocardioides simplex comb. nov. Archives of Microbiology 133, 323-329.

Phillips, P. G., Dunphy, P. J., Servis, K. L. \& BRoDIE, A. F. (1971). A new menaquinone series differing in the degree of unsaturation of the side chain. Biochemistry 8, 2856 2861.

Prauser, H. (1976a). Host-phage relationships in nocardioform organisms. In The Biology of the Nocardiae, pp. 266-284. Edited by M. Goodfellow, G. H. Brownell \& J. A. Serrano. London \& New York: Academic Press.

PraUSER, H. (1976b). Nocardioides, a new genus of the order Actinomycetales. International Journal of Systematic Bacteriology 26, 58-65.

Pridham, T. G. \& Lyons, A. J., JR (1969). Progress in clarification of the taxonomic and nomenclatural 
status of some problem actinomycetes. Developments in Industrial Microbiology 10, 183-221.

Pridham, T. G., Anderson, P., Foley, C., Lindenfelser, H. A., Hesseltine, C. W. \& Benedict, R. G. (1956-1957). A selection of media for maintenance and taxonomic study of Streptomyces. Antibiotics Annual 1956-1957, 947-953.

Ridell, M. \& Williams, S. T. (1983). Serotaxonomical analyses of some Streptomyces and related organisms. Journal of General Microbiology 129, 28572861.

Shirling, E. B. \& Gottlieb, D. (1968a). Cooperative description of type cultures of Streptomyces. II. Species description from first study. International Journal of Systematic Bacteriology 18, 69-189.

Shirling, E. B. \& GotTlieb, D. (1968b). Cooperative description of type cultures of Streptomyces. III. Additional species descriptions from first and second studies. International Journal of Systematic Bacteriology 18, 279-391.

Shirling, E. B. \& Gotrlieb, D. (1969). Cooperative description of type cultures of Streptomyces. IV. Species descriptions from the second, third and fourth studies. International Journal of Systematic Bacteriology 19, 391-512.

Shirling, E. B. \& Gottlieb, D. (1972). Cooperative description of type strains of Streptomyces. V. Additional descriptions. International Journal of Systematic Bacteriology 22, 265-394.

Skerman, V. B. D., McGowan, V. \& Sneath, P. H. A. (1980). Approved lists of bacterial names. International Journal of Systematic Bacteriology 30, 225-420.

SNEATH, P. H. A. (1970). Application of numerical taxonomy to Actinomycetales: problems and perspectives. In The Actinomycetales, pp. 371-378. Edited by H. Prauser. Jena: Gustav Fischer Verlag.

Stackebrandt, E. \& Woese, C. R. (1981). The evolution of prokaryotes. In Molecular and Cellular Aspects of Microbial Evolution, pp. 1-31. Edited by M. J. Carlile, J. F. Collins \& B. E. B. Moseley. Cambridge: University Press.

Stackebrandt, E., WüNnER-Fussl, B., Fowler, V. J. \& SCHLEIFER, K. H. (1981). Deoxyribonucleic acid homologies and ribosomal ribonucleic acid similarities among sporeforming members of the order Actinomycetales. International Journal of Systematic Bacteriology 31, 420-431.

Tille, D., Prauser, H., Szyba, K. \& Mordarski, M. (1978). On the taxonomic position of Nocardioides albus Prauser by DNA:DNA hybridization. Zeitschrift für allgemeine Mikrobiologie 18, 459-462.

Wellington, E. M. H. \& Williams, S. T. (1978). Preservation of actinomycete inoculum in frozen glycerol. Microbios Letters 6, 151-157.

Wellington, E. M. H. \& Williams, S. T. (1981). Host ranges of phages isolated to Streptomyces and other genera. Zentralblatt für Bakteriologie, Mikrobiologie und Hygiene (Abteilung I, Supplement II), 93-98.

WILKINSON, B. J. \& JONES, D. (1977). A numerical taxonomic survey of Listeria and related bacteria. Journal of General Microbiology 98, 399-421.

Williams, S. T., Goodfellow, M., Alderson, G., Wellington, E. M. H., Sneath, P. H. A. \& Sackin, M. J. (1983). Numerical classification of Streptomyces and related genera. Journal of General Microbiology 129, 1743-1813.

Yamada, Y., Yamashita, M., Tahara, Y. \& Kondo, K. $(1977 a)$. The menaquinone system in the classification of the genus Actinomadura. Journal of General and Applied Microbiology 23, 331-335.

YAMADA, Y., IshiKaWA, T., TAHARA, Y.\& Kondo, K. $(1977 b)$. The menaquinone system in the classification of the genus Nocardia. Journal of General and Applied Microbiology 23, 207-216.

YAMADA, Y., AOKI, K. \& TAhaRA, Y. (1982a). The structure of hexahydrogenated isoprenoid side-chain menaquinone with nine isoprene units isolated from Actinomadura madurae. Journal of General and Applied Microbiology 28, 321-329.

Yamada, Y., Hou, C. F., Sasaki, J., Tahara, Y. \& YoshioKa, H. (1982b). The structure of the octahydrogenated isoprenoid side-chain menaquinone with nine isoprene units isolated from Streptomyces albus. Journal of General and Applied Microbiology 28, 519529. 